\title{
Determinan Partisipasi Kerja Perempuan dalam Sektor Informal di Indonesia Tahun 2019
}

\author{
(Determinants of Women's Work Participation in the Informal Sector in Indonesia in 2019) \\ Anindya Tyas Wandaweka ${ }^{1}$, Dewi Purwanti² \\ ${ }^{1,2}$ Politeknik Statistika STIS \\ Jalan Otto Iskandardinata No. 64C, Jakarta 13330 \\ E-mail: 111810173@stis.ac.id
}

\begin{abstract}
ABSTRAK
Pasar tenaga kerja yang kondusif dapat mendorong minat perempuan untuk berpartisipasi aktif dalam bidang perekonomian. Namun pada tahun 2019, perempuan cenderung bekerja di sektor informal daripada sektor formal, padahal pekerjaan di sektor informal memiliki risiko kerja yang tinggi, perlindungan yang minim, dan keuntungan yang rendah. Dengan menggunakan data Sakernas Agustus 2019, penelitian ini bertujuan untuk mengetahui gambaran karakteristik perempuan dalam pekerjaan sektor formal dan informal di Indonesia tahun 2019, mengkaji variabel-variabel yang memengaruhinya, serta mengetahui kecenderungan dari variabel-variabel yang memengaruhinya. Metode yang digunakan dalam penelitian ini adalah regresi logistik biner. Hasil penelitian menunjukkan bahwa perempuan di Indonesia yang berumur tua, tingkat pendidikan rendah, tidak pernah mengikuti pelatihan kerja, berstatus pernah kawin dan tinggal di wilayah pedesaan memiliki kecenderungan lebih besar untuk bekerja di sektor informal.
\end{abstract}

Kata kunci: Perempuan, Sektor Informal, Regresi Logistik Biner

\section{ABSTRACT}

A conducive labor market can encourage women's interest to actively participate in the economy. However, in 2019, women tend to work in the informal sector rather than the formal sector, even though work in the informal sector has high work risks, minimal protection, and low benefits. Using Sakernas August data for 2019, this study aims to describe the characteristics of women in formal and informal sector work in Indonesia in 2019, examine the variables that influence them, and determine the tendency of the variables that influence them. The method used in this study is binary logistic regression. The results of the study show that women in Indonesia who are elderly, have low education levels, have never attended job training, have been married and living in rural areas have a greater tendency to work in the informal sector.

Keywords: Women, Informal Sector, Binary Logistic Regression

\section{PENDAHULUAN}

Pembangunan ketenagakerjaan merupakan bagian penting dari pembangunan nasional yang bertujuan menciptakan sumber daya manusia berkualitas. Pembangunan ketenagakerjaan tercakup dalam Tujuan Pembangunan Berkelanjutan atau Sustainable Development Goals (SDGs) yang terdapat pada tujuan kedelapan dengan bahasan mengenai dukungan terhadap pertumbuhan ekonomi yang inklusif dan berkelanjutan, tenaga kerja penuh dan produktif, serta pekerjaan yang layak untuk semua. Tujuan kedelapan ini memiliki sepuluh target yang ingin dicapai, dua diantaranya menjadikan tenaga kerja perempuan sebagai perhatian utama, yaitu pada target kelima dan target kedelapan. Target kelima menyebutkan bahwa adanya keinginan untuk mencapai pekerjaan yang penuh dan produktif, serta pekerjaan yang layak baik untuk seluruh laki-laki maupun perempuan, termasuk pemuda dan penyandang disabilitas, serta adanya kesetaraan upah bagi pekerjaan yang sejenis. Sementara itu, target kedelapan membahas perlindungan hak-hak tenaga kerja dan penyediaan lingkungan kerja yang aman bagi seluruh pekerja, khususnya pekerja migran perempuan dan pekerja dengan pekerjaan yang berbahaya.

Menurut KemenPPA (2016), pembangunan pada pasar tenaga kerja dapat memperbaiki kualitas hidup perempuan. Hal ini dapat dilakukan dengan menciptakan pasar kerja yang kondusif. Ini bertujuan untuk mendorong minat perempuan agar berpartisipasi aktif dalam bidang ekonomi, sehingga dapat memperbaiki kualitas hidup dan meningkatkan pemberdayaan perempuan. Namun menurut Das \& Kotikula (2018), perempuan kerapkali dibatasi oleh norma-norma sosial dalam memilih jenis pekerjaan. Perempuan dituntut untuk dapat menyeimbangkan antara beban pekerjaan di tempat kerja dengan bebannya dalam mengurus 
rumah tangga, sehingga perempuan membutuhkan pekerjaan dengan fleksibilitas waktu yang ditawarkan untuk menyeimbangkan kedua hal tersebut. Perempuan cenderung memilih pekerjaan yang memiliki fleksibilitas pada jam kerja, salah satunya adalah bekerja pada sektor informal.

Badan Pusat Statistik (BPS) pada Agustus 2019 melalui Survei Angkatan Kerja Nasional (Sakernas) melaporkan bahwa terdapat 70,49 juta jiwa (55,72 persen) yang bekerja pada sektor informal di Indonesia. Sementara itu, 56,01 juta jiwa (44,28 persen) bekerja pada sektor formal. Jika ditinjau berdasarkan jenis kelamin, perempuan mendominasi pada sektor pekerjaan informal daripada formal. Perempuan yang bekerja pada sektor informal di Indonesia sebesar 60,81 persen, sedangkan 39,19 persen lainnya bekerja pada pekerjaan sektor formal. Sementara itu, persentase laki-laki pada sektor pekerjaan formal dan informal hampir berimbang, dimana sebanyak 52,81 persen bekerja pada sektor informal dan 47,19 persen lainnya bekerja pada sektor formal.

Sektor pekerjaan informal umumnya merupakan usaha mandiri, penggunaan teknologi sederhana, modal yang kecil, dan relatif tidak terorganisir. Hal ini menyebabkan sektor informal identik dengan aktivitas ekonomi berskala kecil, produktivitas dan keuntungan yang rendah (Taufiq, 2017). Nazara (2010) mengungkapkan bahwa keberadaan sektor pekerjaan informal yang lebih besar daripada sektor formal dapat menjadi penghambat dalam menurunkan angka kemiskinan. Ini disebabkan sektor informal umumnya berkaitan dengan upah yang rendah, risiko kerja yang tinggi, dan perlindungan yang minim. Selain itu, hubungan antara buruh dan majikan biasanya hanya berdasarkan perjanjian/kontrak kerja yang tidak tertulis (lisan). Jenis perjanjian/kontrak ini dapat merugikan pihak yang memiliki kedudukan rendah, yaitu para buruh (Safaria et al., 2003).

Rosemary Atieno (2006) dalam penelitiannya mengenai faktor-faktor yang memengaruhi perempuan bekerja pada sektor informal di Kenya menggunakan metode regresi multinomial logit menyimpulkan bahwa variabel umur, tingkat pendidikan terakhir, status perkawinan, dan lokasi tempat tinggal berpengaruh secara signifikan terhadap partisipasi kerja perempuan di sektor informal. Penelitian lainnya yakni oleh Isti'Any dan Pitoyo (2016) menyebutkan bahwa umur, tingkat pendidikan, status perkawinan, dan jumlah anak berpengaruh secara signifikan terhadap partisipasi kerja perempuan di sektor informal. Penelitian yang dilakukan oleh Muryani dan Ginanti Permata Hatiku (2019) menyimpulkan bahwa umur, status perkawinan, wilayah tempat tinggal, tingkat pendidikan, dan pendapatan memengaruhi secara signifikan terhadap partisipasi kerja perempuan dalam sektor informal.

Dengan mengidentifikasi variabel-variabel yang memengaruhi partisipasi perempuan dalam pekerjaan informal di Indonesia melalui karakteristiknya, maka diharapkan akan mengarah pada kebijakan nasional untuk meningkatkan kualitas perempuan yang dapat membawanya menuju kondisi pekerjaan yang lebih baik. Oleh karena itu, penelitian ini bertujuan untuk mengetahui gambaran karakteristik pekerja perempuan pada sektor formal dan informal di Indonesia tahun 2019, mengetahui variabel-variabel yang memengaruhi partisipasi perempuan dalam sektor informal di Indonesia tahun 2019, serta kecenderungan dari variabelvariabel yang memengaruhi. Variabel-variabel dalam penelitian ini yang diduga memiliki pengaruh signifikan terhadap partisipasi kerja perempuan dalam sektor informal adalah umur, tingkat pendidikan, status pelatihan kerja, status perkawinan dan wilayah tempat tinggal. Dengan demikian, hipotesis yang didapatkan dalam penelitian ini adalah masing-masing variabel independen, yaitu umur, tingkat pendidikan, status pelatihan kerja, status perkawinan, dan wilayah tempat tinggal berpengaruh terhadap partisipasi kerja perempuan dalam sektor informal di Indonesia tahun 2019.

\section{METODE}

\section{Landasan Teori}

ICLS ke 17 mendefinisikan bahwa pekerja informal pada umumnya memiliki hubungan kerja yang tidak tunduk pada undang-undang tenaga kerja, minim perlindungan sosial atau hak tertentu untuk jaminan kerja tertentu. Tenaga kerja di sektor informal terdiri dari pekerja sektor konstruksi, pekerja rumah tangga, produsen rumahan, pedagang kaki lima, pekerja angkutan, pemulung dan pekerja lainnya yang bekerja di lingkungan kerja yang berbahaya (UN-HABITAT, 2016). Sementara itu, Mazumdar (1989) menjelaskan bahwa sektor formal mencakup pekerjaan di sektor publik dan swasta. Badan Pusat Statistik membedakan tenaga kerja formal dan informal berdasarkan status pekerjaan utama. Tenaga kerja dengan status pekerjaan berusaha dibantu buruh tetap/dibayar atau buruh/karyawan/pegawai merupakan tenaga kerja formal. Sementara itu, tenaga kerja dengan status pekerjaan berusaha sendiri, berusaha dibantu buruh tidak tetap/buruh tidak dibayar, pekerja bebas di pertanian, pekerja bebas non pertanian, ataupun pekerja keluarga/pekerja tidak dibayar termasuk pekerja informal. 
Gundogan dan Bicerli (2009) menyebutkan bahwa ada beberapa alasan yang menyebabkan perempuan berkontribusi pada sektor informal. Pertama, yaitu akibat tingginya tingkat pengangguran yang menyebabkan perempuan kehilangan kesempatan kerja di sektor formal. Kedua adalah akibat keterampilan yang rendah, kondisi budaya, dan tanggung jawab terhadap keluarga menyebabkan perempuan memilih untuk bekerja di sektor informal. Ketiga yaitu turunnya pendapatan rumah tangga akibat krisis ekonomi menyebabkan perempuan berpartisipasi dalam pasar kerja untuk menambah pendapatan rumah tangga. Ketidakadaan struktur formal yang menjelaskan persyaratan mengenai penerimaan dan pengeluaran para pekerja sektor informal menyebabkan angkatan kerja yang berpendidikan rendah mudah diterima karena tidak terdapat spesifikasi batasan tingkat pendidikan (The World Bank, 2011). Begitu juga halnya dengan keterampilan yang dimiliki. Menurut Gupta (2014), sektor informal memberikan sumber pendapatan yang mudah bagi perempuan tidak terampil. Sektor ini umumnya tidak memiliki persyaratan untuk memasukinya, seperti keterampilan, pengalaman pelatihan, dan syarat lain yang ada di sektor formal. Selanjutnya, tanggung jawab terhadap keluarga juga memengaruhi partisipasi kerja perempuan dalam sektor informal. Menurut Sumule dan Syafitri (2013), perempuan yang pernah kawin mayoritas bekerja pada sektor informal. Kondisi ini terjadi akibat setelah menikah, perempuan cenderung memiliki keterbatasan untuk berpartisipasi secara penuh dalam pekerjaannya, sehingga pekerjaan sektor informal menjadi salah satu cara bagi perempuan untuk menyeimbangkan kedua hal tersebut, yaitu bekerja dan mengurus rumah tangga karena pekerjaan sektor informal ini menawarkan kebebasan dalam mengatur waktu kerja. Selain itu umur juga berpengaruh terhadap partisipasi kerja perempuan di sektor informal. Mabilo (2018) mengungkapkan bahwa perempuan yang berusia tua lebih suka menghabiskan waktunya untuk bekerja di sektor informal dibandingkan perempuan yang berusia muda. Kondisi kesehatan yang semakin menurun akibat pertambahan usia menyebabkannya harus mencari pekerjaan dengan fleksibilitas pada jam kerja. Dalam hal ini, pekerjaan sektor informal lebih memungkinkan daripada sektor formal karena merupakan pekerjaan yang fleksibel dan tidak ada tekanan dalam bekerja. Variabel lainnya yang terindikasi berpengaruh terhadap partisipasi kerja di sektor informal adalah wilayah tempat tinggal. Pekerja informal umumnya lebih terkonsentrasi di daerah pedesaan. Hal ini disebabkan Hal ini disebabkan wilayah pedesaan erat kaitannya dengan tingkat pendidikan yang rendah, sulitnya mengakses pelayanan dan infrastruktur umum, kualitas layanan pemerintah yang berbeda dengan daerah perkotaan, serta persepsi dan tradisi masyarakat pedesaan yang berbeda dengan daerah perkotaan (OECD/ILO, 2019).

\section{Cakupan Penelitian}

Penelitian ini mencakup penduduk perempuan usia 15 tahun ke atas yang memiliki pekerjaan, baik yang sedang bekerja maupun mereka yang sementara tidak bekerja di Indonesia tahun 2019. Data yang digunakan berasal dari raw data Survei Angkatan Kerja Nasional (Sakernas) Agustus tahun 2019. Metode pengumpulan datanya berupa wawancara langsung dengan menggunakan kuesioner Daftar SAK19.AK sebagai instrumennya. Variabel dalam penelitian ini terdiri dari variabel dependen dan variabel independen. Variabel dependen yang digunakan adalah sektor pekerjaan perempuan yang terdiri dari dua kategori, yaitu formal dan informal. Sementara itu, variabel independennya meliputi umur, tingkat pendidikan, status perkawinan, status pelatihan kerja, dan wilayah tempat tinggal.

\section{Metode Analisis}

Metode analisis yang digunakan berupa analisis deskriptif dan analisis inferensia. Analisis deskriptif dalam penelitian ini menggunakan grafik dan tabel yang bertujuan untuk mengetahui gambaran umum terkait karakteristik pekerja perempuan pada sektor formal dan informal di Indonesia tahun 2019. Sementara itu, analisis inferensia dilakukan dengan metode regresi logistik biner yang bertujuan untuk mengetahui variabel independen apa saja yang berpengaruh signifikan terhadap partisipasi perempuan dalam sektor pekerjaan informal di Indonesia tahun 2019 serta kecenderungan dari variabel-variabel yang memengaruhinya. Regresi logistik biner merupakan metode yang digunakan untuk mengetahui huungan antara variabel dependen (Y) yang dipengaruhi oleh satu atau lebih variabel independen $(\mathrm{X})$, dimana variabel dependennya berupa data biner atau dikotomi (Hosmer \& Lemeshow, 2013). Dalam penelitian ini, variabel dependennya terdiri dari dua kategori, yaitu sektor formal dan informal, sehingga regresi logistik biner adalah metode yang paling sesuai. Adapun tahapan regresi logistik biner sebagai berikut:

1) Pendugaan Parameter dan Pembentukan model.

Pendugaan parameter menggunakan maximum likelihood estimation (MLE). Metode ini digunakan untuk mengestimasi parameter dengan cara memaksimalkan fungsi likelihood. Fungsi ini menyatakan nilai peluang dari data yang diamati sebagai fungsi dari parameter yang tidak diketahui (Hosmer dan Lemeshow, 2013). Berdasarkan Hosmer dan Lemeshow (2013) model regresi yang terbentuk dalam 
penelitian ini adalah sebagai berikut:

$g(D)=\beta_{0}+\beta_{11} D_{11}+\beta_{12} D_{12}+\beta_{2} D_{2}+\beta_{3} D_{3}+\beta_{4} D_{4}+\beta_{5} D_{5}$

Keterangan:

D : Sektor Pekerjaan Perempuan [0 = formal ; $1=$ informal $]$

$\mathrm{D}_{11}$ : Variabel dummy untuk umur (25-59 tahun)

$\mathrm{D}_{12}$ : Variabel dummy untuk umur ( $\geq 60$ tahun)

$\mathrm{D}_{2}$ : Variabel dummy untuk tingkat pendidikan

$\mathrm{D}_{3}$ : Variabel dummy untuk status pelatihan kerja

$\mathrm{D}_{4}$ : Variabel dummy untuk status perkawinan

$\mathrm{D}_{5}$ : Variabel dummy untuk status daerah tempat tinggal

2) Pengujian kesesuaian model yang dilakukan dengan menggunakan kurva Receiver Operating Characteristic (ROC) dan tabel klasifikasi. Menurut Hosmer dan Lemeshow (2013), kurva ROC merupakan hasil plot antara true signal (sensitivity) dengan false signal (1-specificity) untuk seluruh cut point yang memungkinkan. Sementara itu, tabel klasifikasi merupakan hasil klasifikasi silang antara variabel dependen (y) dengan variabel dikotomis yang nilainya berasal dari perkiraan probabilitas logistik (predicted).

3) Pengujian signifikansi yang dilakukan sebagai berikut:

- Uji Simultan

Pengujian secara simultan dilakukan untuk memeriksa pengaruh semua variabel independen terhadap variabel dependen secara bersama-sama (Hosmer dan Lemeshow, 2013).

$\mathrm{H}_{0}: \beta 1=\beta 2=\ldots \beta 6=0$ (tidak ada variabel independen yang signifikan secara simultan terhadap partisipasi kerja perempuan dalam sektor informal atau model tidak dapat menjelaskan hubungan antar variabel)

$\mathrm{H}_{1}$ : minimal terdapat satu $\beta \mathrm{j} \neq 0$ (artinya minimal ada satu variabel independen yang signifikan terhadap partisipasi kerja perempuan dalam sektor informal atau model dapat menjelaskan hubungan antar variabel)

$\mathrm{j}=1,2, \ldots .6$

Statistik uji: Likelihood Ratio Test $(\mathrm{G})$

Jika $\mathrm{G}>\chi_{(0,05 ; 6)}^{2}$ atau p-value $<0,05$ maka akan menghasilkan keputusan tolak $\mathrm{H}_{0}$, sehingga dapat diambil kesimpulan dengan tingkat signifikansi lima persen, minimal terdapat satu variabel independen yang berpengaruh terhadap partisipasi kerja perempuan dalam sektor informal.

- Uji Parsial

Pengujian secara parsial dilakukan untuk melihat pengaruh dari setiap variabel independen terhadap variabel dependen, sehingga dapat ditemukan variabel independen mana yang memiliki pengaruh secara signifikan terhadap variabel dependen.

$\mathrm{H}_{0}: \beta \mathrm{j}=0$ (tidak ada pengaruh signifikan variabel independen ke-j terhadap partisipasi kerja perempuan dalam sektor informal).

$\mathrm{H}_{1}: \beta \mathrm{j} \neq 0$ (ada pengaruh signifikan variabel independen ke-j terhadap partisipasi kerja perempuan dalam sektor informal)

$\mathrm{j}=1,2, \ldots .6$

Statistik uji: Wald test $\left(\mathrm{W}^{2}\right)$

Jika nilai $\mathrm{W}^{2}>\chi_{(0,05 ; 1)}^{2}$ atau $\mathrm{p}$-value $<0,05$ maka diperoleh keputusan untuk menolak $\mathrm{H}_{0}$, sehingga dapat diambil kesimpulan dengan tingkat signifikansi lima persen, terdapat variabel independen ke-j yang diuji berpengaruh signifikan terhadap partisipasi kerja perempuan dalam sektor informal.

4) Interpretasi pada odds ratio. Odds ratio digunakan untuk melihat kecenderungan variabel-variabel independen terhadap variabel-variabel dependen.

\section{HASIL DAN PEMBAHASAN}

\section{Gambaran Karakteristik Pekerja Perempuan pada Sektor Formal dan Informal di Indonesia Tahun 2019}

Data Survei Angkatan Kerja Nasional (Sakernas) tahun 2019 yang ditunjukkan melalui Gambar 1 mencatat bahwa sebanyak 60,8 persen perempuan di Indonesia bekerja di sektor informal. Nilai ini cukup tinggi jika dibandingkan dengan pekerja perempuan di sektor formal yang sebesar 39,2 persen. Kondisi ini 
memberi arti bahwa mayoritas pekerja perempuan di Indonesia tahun 2019 terpusat pada pekerjaan sektor informal.

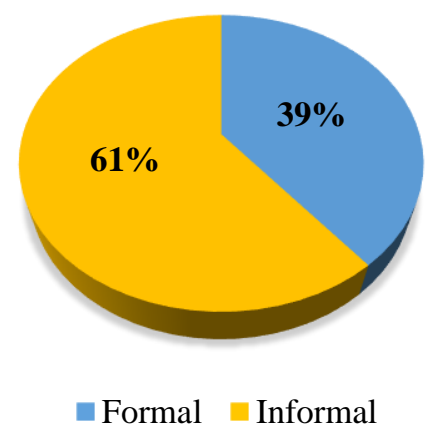

Sumber: Sakernas Agustus 2019

Gambar 1. Persentase pekerja perempuan pada sektor formal dan informal di Indonesia tahun 2019

Perempuan yang bekerja pada sektor formal dan informal dapat diidentifikasi berdasarkan status pekerjaannya. Perempuan yang bekerja di sektor formal memiliki status pekerjaan sebagai pekerja yang berusaha dibantu buruh tetap/dibayar dan buruh/karyawan/pegawai. Sementara itu, perempuan yang bekerja di sektor informal mencakup status pekerjaan sebagai pekerja yang berusaha sendiri, berusaha dengan dibantu buruh tidak tetap, pekerja bebas di pertanian, pekerja bebas di non pertanian, dan pekerja keluarga/tidak dibayar. Gambar 2 memperlihatkan proporsi dari pekerja perempuan pada sektor formal dan informal di Indonesia tahun 2019 berdasarkan status pekerjaannya. Gambar tersebut menunjukkan bahwa pekerja perempuan pada sektor formal di Indonesia tahun 2019 mayoritas berstatus sebagai buruh/karyawan/pegawai. Sementara itu, perempuan yang bekerja pada sektor informal mayoritas merupakan pekerja keluarga/tidak dibayar dan pekerja yang berusaha sendiri, sedangkan sektor pekerjaan di sektor informal yang paling sedikit digeluti oleh perempuan adalah pekerja bebas baik di pertanian maupun non pertanian.

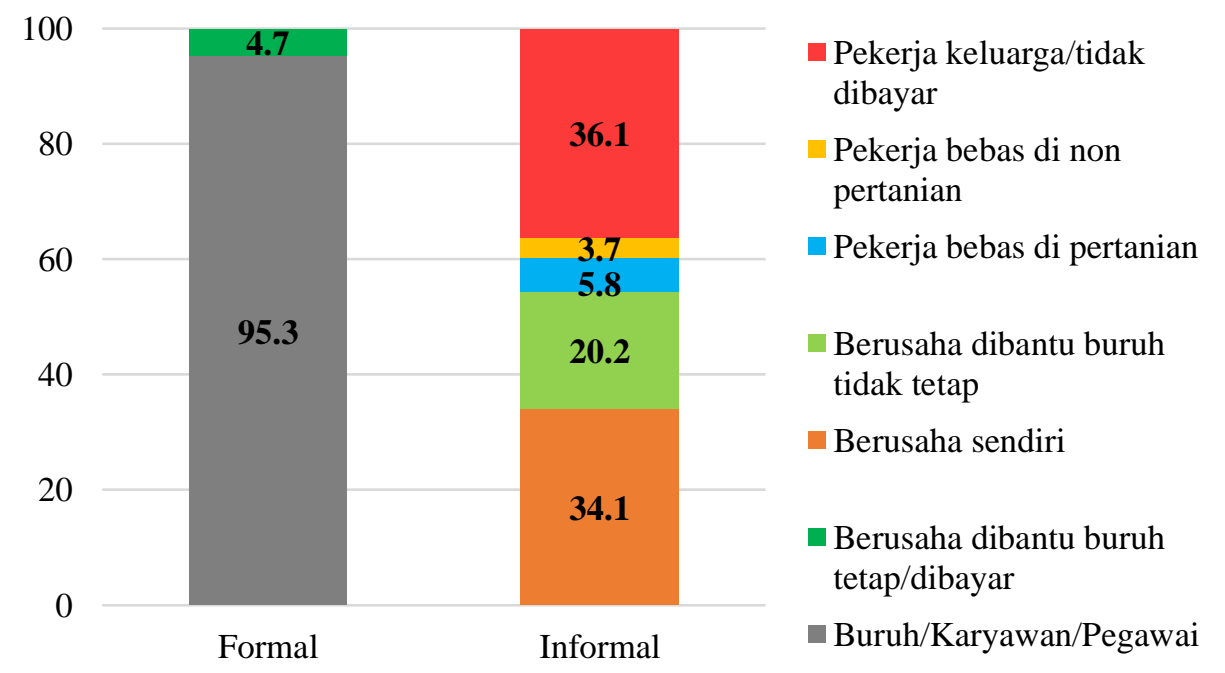

Sumber: Sakernas Agustus 2019 (diolah)

Gambar 2. Persentase pekerja perempuan pada sektor formal dan informal berdasarkan status pekerjaan utama di Indonesia tahun 2019

Karakteristik pekerja perempuan pada sektor formal dan informal ditunjukkan melalui tabel 1. Tabel tersebut menunjukkan bahwa perempuan yang bekerja di sektor informal mayoritas berumur tua ( $\geq 60$ tahun), berpendidikan rendah $(\leq \mathrm{SMP} /$ sederajat), tidak pernah mengikuti pelatihan kerja, berstatus pernah kawin, dan tinggal di wilayah pedesaan. 
Tabel 1. Persentase sektor pekerjaan perempuan berdasarkan variabel independen di Indonesia tahun 2019

\begin{tabular}{|c|c|c|c|c|}
\hline \multirow{2}{*}{\multicolumn{2}{|c|}{ Variabel }} & \multicolumn{2}{|c|}{ Sektor Pekerjaan } & \multirow{2}{*}{ Total } \\
\hline & & Formal & Informal & \\
\hline \multirow[t]{3}{*}{ Umur } & $0: 15-24$ tahun & $66,2 \%$ & $33,8 \%$ & $100 \%$ \\
\hline & 1: 25-59 tahun & $38 \%$ & $62 \%$ & $100 \%$ \\
\hline & $2: \geq 60$ tahun & $10,8 \%$ & $89,2 \%$ & $100 \%$ \\
\hline \multirow[t]{2}{*}{ Tingkat Pendidikan } & 0: >SMP/sederajat & $65,7 \%$ & $34,3 \%$ & $100 \%$ \\
\hline & $1: \leq \mathrm{SMP} /$ sederajat & $20,5 \%$ & $79,5 \%$ & $100 \%$ \\
\hline \multirow[t]{2}{*}{ Status Pelatihan Kerja } & 0: Pernah Mengikuti & $70 \%$ & $30 \%$ & $100 \%$ \\
\hline & 1: Tidak Pernah Mengikuti & $35,6 \%$ & $64,4 \%$ & $100 \%$ \\
\hline \multirow[t]{2}{*}{ Status Perkawinan } & 0: Belum Pernah Kawin & $74,1 \%$ & $25,9 \%$ & $100 \%$ \\
\hline & 1: Pernah Kawin & $32,5 \%$ & $67,5 \%$ & $100 \%$ \\
\hline \multirow[t]{2}{*}{ Wilayah Tempat Tinggal } & 0: Perkotaan & $51,5 \%$ & $48,5 \%$ & $100 \%$ \\
\hline & 1: Pedesaan & $24,4 \%$ & $75,6 \%$ & $100 \%$ \\
\hline
\end{tabular}

Sumber: Sakernas Agustus 2019 (diolah)

\section{Variabel-variabel yang Memengaruhi Partisipasi Kerja Perempuan dalam Sektor Informal}

Setelah mendapatkan gambaran sektor pekerjaan formal dan informal pada pekerja perempuan di Indonesia tahun 2019 berdasarkan karakteristiknya, maka langkah berikutnya adalah melakukan analisis inferensia untuk melihat variabel-variabel apa saja yang memengaruhi partisipasi kerja perempuan dalam sektor informal di Indonesia dengan menggunakan lima variabel yang diduga memiliki pengaruh terhadap sektor pekerjaan pekerja perempuan, yaitu umur, tingkat pendidikan, status pelatihan kerja, status perkawinan, dan wilayah tempat tinggal.

\section{Pengujian Kesesuaian Model}

Pengujian kesesuaian model dilakukan untuk mengetahui apakah model yang terbentuk sudah sesuai dalam menjelaskan hubungan antara variabel independen dengan sektor pekerjaan pekerja perempuan di Indonesia. Uji kesesuaian model dalam penelitian ini menggunakan tabel klasifikasi dan kurva Receiver Operating Characteristic (ROC).

Kurva Receiver Operating Characteristic (ROC) digunakan untuk melihat kesesuaian model dalam penelitian ini. Hasil pengolahan pada Gambar 3 menggambarkan kurva yang mendekati angka satu. Hal ini memberi arti bahwa model yang terbentuk sudah sesuai dalam menjelaskan hubungan antara lima variabel independen dengan sektor pekerjaan formal dan informal pada pekerja perempuan di Indonesia tahun 2019.

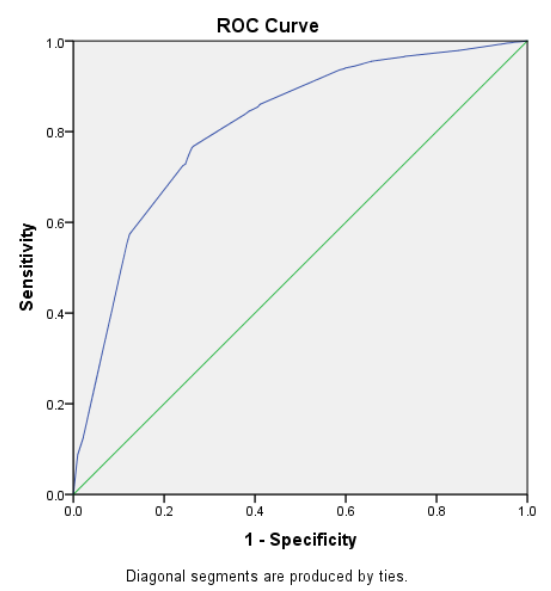

Sumber: Sakernas Agustus 2019 (diolah)

\section{Gambar 3. Kurva ROC}

Selain itu, dari hasil pengolahan juga didapatkan besar luas area di bawah kurva ROC dengan selang kepercayaan sebesar 95 persen. Hal ini ditunjukkan melalui Tabel 2. Luas area di bawah kurva ROC yang diperoleh adalah sebesar 0,810. Nilai tersebut termasuk dalam kategori excellent discrimination. Menurut Hosmer dan Lemeshow (2013), nilai minimal dari luas area di bawah kurva ROC agar model dapat diterima 
adalah sebesar 0,700. Dengan demikian, luas area di bawah kurva ROC yang dihasilkan dalam penelitian ini sudah melebihi nilai minimal yang telah ditentukan, sehingga model yang terbentuk sudah dapat diterima.

Tabel 2. Hasil luas area di bawah kurva ROC regresi logistik biner

\begin{tabular}{ccccc}
\hline \multirow{2}{*}{ Area } & \multirow{2}{*}{ Std. Error } & \multirow{2}{*}{ Asymptotic Sig. } & \multicolumn{2}{c}{ Asymptotic 95\% Confidence Interval } \\
\cline { 4 - 5 } & 0,001 & 0,000 & Lower Bound & Upper Bound \\
\hline 0,810 & & & 0,808 & 0,812 \\
\hline
\end{tabular}

Sumber: Sakernas Agustus 2019 (diolah)

Uji kesesuaian lain yang digunakan dalam penelitian ini adalah tabel klasifikasi. Tabel klasifikasi digunakan untuk melihat ketepatan model dalam mengklasifikasikan perempuan yang bekerja pada sektor formal dan sektor informal di Indonesia. Hal ini ditunjukkan melalui Tabel 3. Tabel tersebut menunjukkan bahwa persentase total ketepatan klasifikasi adalah sebesar 75,7 persen. Hal ini memberi arti bahwa model tersebut secara keseluruhan dapat mengklasifikasikan perempuan yang bekerja di sektor formal dan sektor informal dengan tepat sebesar 75,7 persen dan sisanya diklasifikasikan secara salah.

Tabel 3. Tabel Klasifikasi

\begin{tabular}{ccccc}
\hline \multirow{2}{*}{ Observed } & \multicolumn{2}{c}{ Predicted } & \multirow{2}{*}{ Percentage Correct } \\
\cline { 3 - 4 } & & formal & informal & \\
\cline { 3 - 5 } & & 50649 & 18203 & 73,6 \\
\multirow{2}{*}{ Sektor Pekerjaan } & formal & 31311 & 103663 & 76,8 \\
\hline \multicolumn{2}{c}{ Overall Percentage } & & & 75,7 \\
\hline
\end{tabular}

Sumber: Sakernas Agustus 2019 (diolah)

Selain itu, nilai sensitivity yang diperoleh adalah sebesar 76,8 persen. Hal ini memberi arti bahwa model tersebut diprediksi mampu mengklasifikasikan perempuan yang bekerja di sektor informal dengan tepat sebagai perempuan yang bekerja di sektor informal sebesar 76,8 persen. Sementara itu, nilai specificity yang didapatkan sebesar 73,6 persen. Ini memberi arti bahwa model tersebut diprediksi mampu mengklasifikasikan perempuan yang bekerja di sektor formal dengan tepat sebagai perempuan yang bekerja di sektor formal sebesar 73,6 persen. Nilai tabel klasifikasi tersebut diperoleh dengan menggunakan cut point yang optimal, yaitu sebesar 0,594. Nilai cut point tersebut didapatkan dari pendekatan kurva Receiver Operating Characteristic (ROC).

\section{Uji Simultan}

Uji simultan dilakukan untuk mengetahui apakah variabel independen memengaruhi partisipasi kerja perempuan dalam sektor informal secara bersama-sama. Pengujian ini dilakukan dengan menggunakan nilai chi-square dan $p$-value yang terdapat pada Tabel 4. Nilai chi-square yang diperoleh adalah sebesar 60.625,076. Nilai ini lebih besar daripada nilai chi square tabel yang sebesar 12,59. Selain itu, $p$-value yang diperoleh sebesar 0,000 . Nilai $p$-value ini lebih kecil dari $\alpha=0,05$, sehingga keputusan yang diambil adalah menolak $\mathrm{H}_{0}$. Dengan demikian, dapat disimpulkan bahwa dengan tingkat signifikansi lima persen, terdapat cukup bukti untuk menyatakan minimal ada satu variabel independen dalam penelitian ini yang berpengaruh secara signifikan terhadap partisipasi kerja perempuan dalam sektor informal di Indonesia tahun 2019.

Tabel 4. Hasil Pengujian Secara Simultan

\begin{tabular}{ccc}
\hline Chi-square & $d f$ & $p$-value \\
\hline $60.625,076$ & 6 & 0,000 \\
\hline
\end{tabular}

Sumber: Sakernas Agustus 2019 (diolah)

\section{Uji Parsial}

Setelah mendapatkan keputusan tolak $\mathrm{H}_{0}$ pada pengujian secara simultan, maka dilakukan pengujian secara parsial untuk mengetahui variabel independen mana saja yang memiliki pengaruh terhadap partisipasi kerja perempuan dalam sektor informal di Indonesia tahun 2019. Pengujian ini menggunakan statistik uji wald dengan hasil sebagai berikut: 
Tabel 5. Hasil Pengujian Secara Parsial

\begin{tabular}{|c|c|c|c|c|c|c|c|}
\hline Variabel & Kategori & Simbol & $\hat{\beta}$ & Wald & $d f$ & $\begin{array}{c}p- \\
\text { value }\end{array}$ & $\begin{array}{l}\text { Odds } \\
\text { Ratio }\end{array}$ \\
\hline \multirow{3}{*}{ Umur } & $15-24$ tahun & - & & & & & \\
\hline & 25-59 tahun & $D_{11}$ & 0,055 & 6,734 & 1 & 0,000 & 1,057 \\
\hline & $\geq 60$ tahun & $D_{12}$ & 0,958 & 855,767 & 1 & 0,000 & 2,606 \\
\hline Tingkat pendidikan & $\begin{array}{l}>\text { SMP/sederajat } \\
\leq \mathrm{SMP} / \text { sederajat }\end{array}$ & $\begin{array}{c}- \\
D_{2}\end{array}$ & 1,606 & $18.437,678$ & 1 & 0,000 & 4,980 \\
\hline Status pelatihan kerja & $\begin{array}{l}\text { Pernah mengikuti } \\
\text { Tidak pernah mengikuti }\end{array}$ & - & 0,969 & $3.058,983$ & 1 & 0,000 & 2,635 \\
\hline Status perkawinan & $\begin{array}{l}\text { Belum kawin } \\
\text { Pernah kawin }\end{array}$ & $\begin{array}{c}- \\
D_{4}\end{array}$ & 0,889 & $1.985,986$ & 1 & 0,000 & 2,432 \\
\hline Wilayah tempat tinggal & $\begin{array}{l}\text { Perkotaan } \\
\text { Pedesaan }\end{array}$ & $\begin{array}{c}- \\
D_{5}\end{array}$ & 0,809 & $5.238,958$ & 1 & 0,000 & 2,245 \\
\hline Constant & & & $-2,347$ & $10.137,190$ & 1 & 0.000 & 0,096 \\
\hline
\end{tabular}

Sumber: Sakernas Agustus 2019 (diolah)

Tabel 5 menunjukkan bahwa seluruh variabel independen dalam penelitian ini memiliki p-value yang lebih kecil daripada 0,05 , sehingga keputusan yang diperoleh adalah menolak $\mathrm{H}_{0}$. Oleh karena itu, dapat disimpulkan bahwa dengan tingkat signifikansi lima persen, terdapat cukup bukti untuk menyatakan masing-masing variabel independen dalam penelitian ini yang terdiri dari umur, tingkat pendidikan, status pelatihan kerja, status perkawinan, dan wilayah tempat tinggal berpengaruh secara signifikan terhadap partisipasi kerja perempuan dalam sektor informal di Indonesia.

Dari hasil pengujian secara parsial tersebut, diperoleh persamaan yang dapat menjelaskan karakteristik sektor pekerjaan pekerja perempuan di Indonesia tahun 2019, yaitu:

$\hat{g}(D)=-2,347+0,055 D_{11}+0,958 D_{12}+1,606 D_{2}+0,969 D_{3}+0,889 D_{4}+0,809 D_{5}$

Keterangan:

D : Sektor Pekerjaan Perempuan $[0=$ formal; $1=$ informal $]$

$\mathrm{D}_{11}$ : Variabel dummy untuk umur (25-59 tahun)

$\mathrm{D}_{12}$ : Variabel dummy untuk umur ( $\geq 60$ tahun)

$\mathrm{D}_{2}$ : Variabel dummy untuk tingkat pendidikan ( $\leq \mathrm{SMP} /$ sederajat $)$

$\mathrm{D}_{3}$ : Variabel dummy untuk status pelatihan kerja (Tidak pernah mengikuti)

$\mathrm{D}_{4}$ : Variabel dummy untuk status perkawinan (Pernah kawin)

$\mathrm{D}_{5}$ : Variabel dummy untuk status daerah tempat tinggal (Pedesaan)

Kecenderungan dari Variabel-variabel yang Memengaruhi Partisipasi Kerja Perempuan dalam Sektor Informal

Kecenderungan dari suatu kategori tertentu dengan kategori referensi dalam setiap variabel independen yang berpengaruh secara signifikan terhadap partisipasi kerja perempuan dalam sektor informal dapat dilihat melalui nilai odds ratio yang ditunjukkan melalui Tabel 6 .

- Umur

Hasil penelitian menunjukkan bahwa umur memiliki pengaruh secara signifikan terhadap partisipasi kerja perempuan dalam sektor informal di Indonesia tahun 2019. Nilai odds ratio yang dimiliki oleh variabel umur pada kategori umur 25-59 tahun sebesar 1,057, artinya perempuan yang berumur 25-59 tahun memiliki kecenderungan 1,057 kali untuk bekerja di sektor informal dibandingkan dengan perempuan berumur 15-24 tahun dengan asumsi variabel lain konstan. Hasil tersebut menunjukkan bahwa perempuan yang berumur 2559 tahun memiliki pengaruh yang pengaruhnya relatif tidak besar. Kondisi ini dapat terjadi akibat bertambahnya jumlah pengangguran usia muda, sehingga mereka memutuskan untuk membantu usaha milik keluarga sebagai pekerja keluarga ataupun bekerja di perusahaan kecil yang tidak terdaftar secara resmi (Gundogan dan Bicerli, 2009). Kan dan Tansel (2014) juga menjelaskan bahwa penduduk usia muda lebih rentan dalam pasar kerja dibandingkan penduduk usia dewasa apabila mereka tidak memiliki pengalaman kerja karena dapat menghambat mereka untuk terserap dalam pekerjaan formal. Selanjutnya, nilai odds ratio yang dimiliki oleh variabel umur pada kategori umur 60 tahun ke atas sebesar 2,606, artinya perempuan yang berumur 60 tahun ke atas memiliki kecenderungan sebesar 2,606 kali untuk bekerja pada sektor informal dibandingkan perempuan berumur 15-24 tahun dengan asumsi variabel lain konstan. Hal ini sejalan dengan Mabilo (2018) bahwa perempuan yang berusia tua lebih suka menghabiskan waktunya untuk bekerja di sektor informal dibandingkan perempuan yang berusia muda. Lemahnya kondisi kesehatan menyebabkannya harus 
mencari pekerjaan dengan fleksibilitas pada jam kerja. Dalam hal ini, pekerjaan sektor informal lebih memungkinkan daripada sektor formal karena merupakan pekerjaan yang fleksibel dan tidak ada tekanan dalam bekerja.

\section{- Tingkat Pendidikan}

Hasil penelitian menunjukkan bahwa tingkat pendidikan memiliki pengaruh secara signifikan terhadap partisipasi kerja perempuan dalam sektor informal di Indonesia tahun 2019. Nilai odds ratio yang dimiliki oleh variabel tingkat pendidikan sebesar 4,980, artinya perempuan dengan tingkat pendidikan yang rendah $(\leq$ SMP/sederajat) memiliki kecenderungan sebesar 4,980 kali dibandingkan dengan perempuan dengan tingkat pendidikan tinggi (> SMP/sederajat) untuk bekerja pada sektor informal dengan asumsi variabel lain konstan. Hal ini sejalan dengan pernyataan The World Bank (2011) bahwa sektor pekerjaan informal umumnya tidak memiliki persyaratan khusus mengenai penerimaan dan pengeluaran pekerjanya. Hal ini menyebabkan angkatan kerja yang berpendidikan rendah mudah diterima karena tidak terdapat spesifikasi batasan tingkat pendidikan di sektor informal. Sementara itu, orang yang memiliki pendidikan tinggi cenderung menginginkan pekerjaan sektor formal.

- $\quad$ Status Pelatihan Kerja

Hasil penelitian menunjukkan bahwa status pelatihan kerja memiliki pengaruh secara signifikan terhadap partisipasi kerja perempuan dalam sektor informal di Indonesia tahun. Nilai odds ratio yang dimiliki oleh variabel status pelatihan kerja sebesar 2,635, artinya perempuan yang tidak pernah mengikuti pelatihan kerja memiliki kecenderungan sebesar 2,635 kali dibandingkan mereka yang pernah mengikuti pelatihan untuk bekerja pada sektor informal dengan asumsi variabel lain konstan. Hal ini sejalan dengan penelitian Gupta (2014) yang menemukan bahwa perempuan tanpa pengalaman pelatihan cenderung mendominasi sektor informal. Hal ini disebabkan sektor ini umumnya tidak memiliki persyaratan untuk memasukinya, seperti keterampilan, pengalaman pelatihan, dan syarat lain yang ada di sektor formal. Inilah yang mendorong perempuan untuk berpartisipasi dalam sektor pekerjaan informal.

- Status Perkawinan

Hasil penelitian menunjukkan bahwa status perkawinan memiliki pengaruh secara signifikan terhadap partisipasi kerja perempuan dalam sektor informal di Indonesia tahun 2019. Nilai odds ratio yang dimiliki oleh variabel status perkawinan sebesar 2,432, artinya, perempuan yang pernah kawin memiliki kecenderungan sebesar 2,432 kali dibandingkan perempuan yang belum kawin untuk bekerja pada sektor informal dengan asumsi variabel lain konstan. Isti'Any dan Pitoyo (2016) juga mengungkapkan hal yang sama bahwa perempuan yang bekerja pada sektor informal didominasi oleh perempuan yang pernah menikah daripada perempuan yang belum menikah karena mayoritas pekerja perempuan yang berstatus belum pernah kawin umumnya tidak memiliki tanggung jawab penuh untuk mengurus rumah tangga, sehingga mereka dapat berpartisipasi secara bebas dalam kegiatan ekonomi. Namun setelah menikah, perempuan cenderung memiliki keterbatasan untuk berpartisipasi secara penuh dalam pekerjaannya.

- Wilayah Tempat Tinggal

Hasil penelitian menunjukkan bahwa wilayah tempat tinggal memiliki pengaruh secara signifikan terhadap partisipasi perempuan dalam sektor pekerjaan informal di Indonesia tahun 2019. Nilai odds ratio yang dimiliki oleh variabel wilayah tempat tinggal sebesar 2,245 , artinya perempuan yang tinggal di wilayah pedesaan memiliki kecenderungan sebesar 2,245 jumlakali dibandingkan perempuan yang tinggal di wilayah perkotaan untuk bekerja pada sektor informal dengan asumsi variabel lain konstan. Tingkat pendidikan yang rendah, pelayanan dan fasilitas umum yang sulit diakses, kualitas pelayanan pemerintahan yang berbeda dengan perkotaan, serta persepsi dan tradisi masyarakat pedesaan yang masih tertinggal dibandingkan daerah perkotaan menyebabkan wilayah pedesaan banyak didominasi oleh sektor pekerjaan informal (OECD/ILO, 2019).

\section{KESIMPULAN}

Kesimpulan dalam penelitian ini yang didapatkan berdasarkan hasil dan pembahasan adalah perempuan di Indonesia tahun 2019 yang bekerja pada sektor informal mayoritas berusia tua ( $\geq 60$ tahun), tingkat pendidikan yang rendah $(\leq \mathrm{SMP} /$ sederajat$)$, tidak pernah mengikuti pelatihan kerja, berstatus pernah kawin, dan tinggal di wilayah pedesaan. Hasil analisis regresi logistik biner menunjukkan bahwa variabel umur, tingkat pendidikan, status pelatihan kerja, status perkawinan, dan wilayah tempat tinggal memengaruhi secara signifikan terhadap partisipasi kerja perempuan pada sektor informal di Indonesia tahun 2019, dimana perempuan di Indonesia yang berusia tua ( $\geq 60$ tahun), tingkat pendidikan rendah ( $\leq \mathrm{SMP} /$ sederajat), tidak pernah mengikuti pelatihan kerja, berstatus pernah kawin dan tinggal di wilayah pedesaan memiliki kecenderungan lebih besar untuk bekerja di sektor informal. 


\section{UCAPAN TERIMA KASIH}

Puji syukur penulis ucapkan ke hadirat Allah SWT yang telah melimpahkan pertolongan-Nya sehingga penulis dapat menyelesaikan penelitian ini. Selain itu, penulis mengucapkan terima kasih kepada Ibu Dewi Purwanti, SST, SE, M.Si yang telah mengarahkan dan membimbing proses penyusunan penelitian ini, Ibu Lia Yuliana, S.Si., M. T. dan Ibu Anugerah Karta Monika, S.Si, ME yang telah memberikan koreksi dan saransaran untuk menyempurnakan penelitian ini, Instansi Badan Pusat Statistik yang telah menyediakan data, serta orang tua dan seluruh pihak yang telah memberikan dukungan maupun membantu penelitian ini.

\section{DAFTAR PUSTAKA}

Atieno, R. (2006). Female participation in the labour market: The case of the informal sector in Kenya By. In Notes (Issue July).

Badan Pusat Statistik. (2019). Indikator Pasar Tenaga Kerja Indonesia Agustus 2019. Jakarta: BPS

Badan Pusat Statistik. (2019). Indikator Pekerjaan Layak di Indonesia 2019. Jakarta: BPS

Cuevas, S., Mina, C., Barcenas, M., \& Rosario, A. (2009). Informal employment in Indonesia. ADB Economics Working Paper Series, 156, 1-44

Das, S., \& Kotikula, A. (2018). Gender-Based Employment Segregation : Understanding Causes and Policy Interventions. 26, 1-61

Dogrul, Gunsel. 2012. Determinants of Formal and Informal Sector Employment in The Urban Areas of Turkey. International Journal of Social Sciences and Humanity Studies Vol 4, No 2, 2012 ISSN: 13098063 (online)

Gundogan, N. dan Bicerli, M. K. (2009). Urbanization And Labor Market Informality In Developing Countries. Munich Personal RePEc Archive Paper, No. 1927

Gupta, K. (2014). Women Working in Informal Sector in India : a Saga of Lopsided Utilization of Human. 1(3), 105-117.

Hosmer, D. W., \& Lemeshow, S. (2013). Applied Logistic Regression Third Edition, USA: John Wiley \& Sons, Inc.

Isti'Any, N. N., \& Pitoyo, A. J. (2016). Pekerja Perempuan Dalam Sektor Informal Di Daerah Istimewa Yogyakarta Analisis Faktor Pengaruh Berdasarkan Susenas Kor 2014. Jurnal Bumi Indonesia, 5(4).

Kan, E. O., \& Tansel, A. (2014). Defining and Measuring Informality in the Turkish Labor Market. SSRN Electronic Journal, 8377.

Kementerian Pemberdayaan Perempuan dan Perlindungan anak. (2016). Potret Ketimpangan Gender dalam Ekonomi. Kementerian Pemberdayaan Perempuan Dan Anak - Badan Pusat Statistik., 15.

Mabilo, M. (2018). Women in the informal economy: Precarious labour in South Africa. March, 1-181.

Mazumdar, Dipak (1989) "Microeconomic Issues of Labour Markets in Developing Countries: Analysis and Policy implications". An EDI Seminar Paper, Economic Development Institute of the World Bank, Washington D.C.

Muryani, M., \& Hatiku, G. P. (2018). Women's Labor Force Participation Analysis on Formal and Informal Business Sectors. Iciebp 2017, 814-817.

Nazara, S. (2010). Informal Economy in Indonesia: Size, Composition, dan Evolution. In International Labour Organization.

OECD/ILO. (2019). Tackling Vulnerability in the Informal Economy. Paris: Development Centre Studies, OECD Publishing.

Safaria, A., Suhanda, D., Riawanti, S. (2003). Hubungan Perburuhan di Sektor Informal ( $1^{\text {st }}$ ed). Bandung: Akatiga

Sumule, F., \& Syafitri, W. (2013). Analysis On Factors Affecting The Participation Of Married Women In Informal Sector (Case studyonTheTradersin Ketawang Gede Sub-district, Malang). Jurnal Ilmiah Mahasiswa FEB, 2(2).

Taufiq, N. (2017). Pengaruh Dinamika Sektor Pekerjaan Terhadap Dinamika Kemiskinan Di Indonesia. Sosio Konsepsia: Jurnal Penelitian Dan Pengembangan Kesejahteraan Sosial Vol. 7, 1-14.

The World Bank (2011). The scope and main characteristics of informal sector employment in Ukraine. Technical note for the Government of Ukraine.

UN-HABITAT. (2016). Enhancing Productivity in the Informal Economy. October. 